\title{
Amycolatopsis tucumanensis sp. nov., a copper- resistant actinobacterium isolated from polluted sediments
}

\author{
Virginia Helena Albarracín, ${ }^{1,2}$ Pablo Alonso-Vega, ${ }^{3}$ Martha E. Trujillo, ${ }^{3}$ \\ María Julia Amoroso ${ }^{1,4}$ and Carlos Mauricio Abate ${ }^{1,2,4}$ \\ ${ }^{1}$ Planta Piloto de Procesos Industriales y Microbiológicos (PROIMI), CONICET, Av. Belgrano y \\ Pasaje Caseros, 4000 Tucumán, Argentina \\ ${ }^{2}$ Facultad de Ciencias Naturales e Instituto Miguel Lillo, Universidad Nacional de Tucumán, 4000 \\ Tucumán, Argentina \\ ${ }^{3}$ Departamento de Microbiología y Genética, Edificio Departamental, Lab. 205, Campus Miguel de \\ Unamuno, Universidad de Salamanca, Salamanca, Spain \\ ${ }^{4}$ Facultad de Bioquímica, Química y Farmacia, Universidad Nacional de Tucumán, 4000 Tucumán, \\ Argentina
}

\begin{abstract}
A novel actinomycete strain, $\mathrm{ABO}^{\top}$, isolated from copper-polluted sediments showed remarkable copper resistance as well as high bioaccumulation abilities. Classical taxonomic methods, including chemotaxonomy and molecular techniques, were used to characterize the isolate. Strain $\mathrm{ABO}^{\top}$ developed a honey-yellow substrate mycelium on all ISP media tested. Abundant, white, aerial mycelium was only formed on ISP 2, 5 and 7 and MM agar. Both types of hyphae fragmented into squarish rod-shaped elements. The aerial mycelium displayed spore-like structures with smooth surfaces in long, straight to flexuous chains. The organism has a type-IV cell wall lacking mycolic acids and type-A whole-cell sugar pattern (meso-diaminopimelic acid, arabinose and galactose) in addition to a phospholipid type-II profile. 16S rRNA gene sequence studies indicated that this organism is a member of the family Pseudonocardiaceae and that it forms a monophyletic clade with Amycolatopsis eurytherma NT202 ${ }^{\top}$. The DNA-DNA relatedness of strain $\mathrm{ABO}^{\top}$ to $A$. eurytherma DSM $44348^{\top}$ was $39.5 \%$. It is evident from these genotypic and phenotypic data that strain $\mathrm{ABO}^{\top}$ represents a novel species in the genus Amycolatopsis, for which the name proposed is Amycolatopsis tucumanensis sp. nov. The type strain is $\mathrm{ABO}^{\top}$ $\left(=\mathrm{DSM} 45259^{\top}=\right.$ LMG $\left.24814^{\top}\right)$.
\end{abstract}

Copper is an essential heavy metal required for numerous enzymic functions in all cells. However, the same chemistry that makes copper essential also makes it a potent cytotoxin when copper homeostatic controls fail (Solioz \& Stoyanov, 2003). Copper's many uses in several industrial applications has led to its wide distribution in soil, silt, waste and wastewater and to significant environmental problems that need to be addressed (Albarracín et al., 2008b). Micro-organisms that are able to accumulate and immobilize toxic metals are considered key tools for the bioremediation of polluted environments (Polti et al.,

The GenBank/EMBL/DDBJ accession number for the $16 \mathrm{~S}$ rRNA gene sequence of strain $\mathrm{ABO}^{\top}$ is $\mathrm{DQ886938}$.

A table showing the fatty acid composition of strain $\mathrm{ABO}^{\top}$, a micrograph of the aerial mycelium of $A$. eurytherma DSM $44348^{\top}$ and an extended neighbour-joining tree based on $16 \mathrm{~S}$ rRNA gene sequences are available as supplementary material with the online version of this paper.
2007; Albarracín et al., 2008a). Because of their great metabolic and morphological diversity, actinobacteria have been proposed as potential tools for remediation biotechnologies (Polti et al., 2007; Schmidt et al., 2005). However, copper resistance in actinobacteria has been little studied (Amoroso et al., 1998; Richards et al., 2002; Schmidt et al., 2005; Albarracín et al., 2005, 2008a, b).

The genus Amycolatopsis, proposed by Lechevalier et al. (1986), has been classified in the family Pseudonocardiaceae by the application of the polyphasic taxonomic approach to actinomycete systematics (Stackebrandt et al., 1997; Kim \& Goodfellow, 1999). It currently contains 39 species with validly published names (http://www.bacterio.cict.fr/a/ amycolatopsis.html), and their representatives have been thoroughly studied because of their important secondary metabolism and applications in medicine and industry (Wink et al., 2004). Recently, Albarracín et al. (2008a) made a report of a copper-resistant Amycolatopsis strain, 
isolated from copper-polluted sediments and designated $\mathrm{ABO}^{\mathrm{T}}$, which has a high bioaccumulation ability and the potential for use in bioremediation biotechnologies.

The actinobacterial strain $\mathrm{ABO}^{\mathrm{T}}$ (code of the culture collection at PROIMI, Tucumán, Argentina) was isolated from groundwater sediments polluted with copper (Albarracín et al., 2005). It was stored at $4{ }^{\circ} \mathrm{C}$ on starchcasein agar slants, containing $\left(\mathrm{l}^{-1}\right): 10.0 \mathrm{~g}$ starch, $1.0 \mathrm{~g}$ casein, $0.5 \mathrm{~g} \mathrm{~K}_{2} \mathrm{HPO}_{4}, 15 \mathrm{~g}$ agar; $\mathrm{pH}$ 7.0. The reference strain Amycolatopsis eurytherma DSM $44348^{\mathrm{T}}$ was included in morphological and physiological studies for comparison.

Morphological and physiological characteristics were observed on various media as described by Shirling \& Gottlieb (1966): yeast extract-malt extract agar (ISP 2), inorganic salts-starch agar (ISP 4), glycerol-asparagine agar (ISP 5), peptone-yeast extract-iron agar (ISP 6) and tyrosine agar (ISP 7). Cultures were incubated for 10 days at $30{ }^{\circ} \mathrm{C}$. Honey-yellow-coloured substrate mycelium developed on all ISP media tested (RAL colour code 1024; Deutsches Institut für Gütesicherung und Kennzeichnung, Reichsausschuß für Lieferbedingungen). White, spore-producing aerial mycelium (RAL colour code 9003) was only formed on ISP 2, 5 and 7 and minimal medium (MM) agar, containing $\left(\mathrm{l}^{-1}\right): 0.5 \mathrm{~g}$ L-asparagine, $0.5 \mathrm{~g} \mathrm{~K}_{2} \mathrm{HPO}_{4}, 0.2 \mathrm{~g} \mathrm{MgSO}_{4} .7 \mathrm{H}_{2} \mathrm{O}, 0.01 \mathrm{~g} \mathrm{FeSO}_{4} .7 \mathrm{H}_{2} \mathrm{O}$, $10.0 \mathrm{~g}$ glucose, $15.0 \mathrm{~g}$ agar; $\mathrm{pH}$ 7.0. Gram and acidalcohol-fast stains were carried out on a 3-day-old culture as described by Doetsch (1981). The cells stained Grampositive and were non-acid-alcohol-fast.

For scanning electron microscopy, cultures were grown on ISP 2 agar. Agar blocks were cut from the growth medium, fixed in $4.25 \%$ glutaraldehyde in $0.1 \mathrm{M}$ phosphate buffer $\left(\mathrm{pH}\right.$ 7.4) for $3 \mathrm{~h}$ at $4{ }^{\circ} \mathrm{C}$ and dehydrated in a graded acetone series. The critical drying point was obtained by exchanging the acetone through liquid $\mathrm{CO}_{2}$. The samples were coated with gold and visualized in a JEOL JSM 35CF scanning electron microscope with $15 \mathrm{kV}$ voltage acceleration. After 7-10 days on ISP 2, strain $\mathrm{ABO}^{\mathrm{T}}$ produced a well-developed branched substrate mycelium as well as a profuse aerial mycelium (Fig. 1). Both types of hyphae fragmented into squarish rod-shaped elements. The aerial mycelium displayed spore-like structures $(0.3 \times 0.8-$ $1.5 \mu \mathrm{m}$ ) with smooth surfaces in long, straight to flexuous chains (Fig. 1). All of these properties are consistent with the classification of the strain in the genus Amycolatopsis. For a comparison, a micrograph of the reference strain $A$. eurytherma DSM $44348^{\mathrm{T}}$ is presented in Supplementary Fig. S1 (available in IJSEM Online).

Utilization of carbohydrates was investigated in ISP 9 (Shirling \& Gottlieb, 1966) by using a 12-well microtitre plate technique. Lysozyme resistance and sodium chloride tolerance were tested on six-well microtitre plates (Wink et al., 2004). Acid production from sugars was determined according to Gordon et al. (1974). A fingerprint of enzymic activities was obtained by using API 20E, API ZYM and API Coryne test strips (bioMérieux). The temperature for

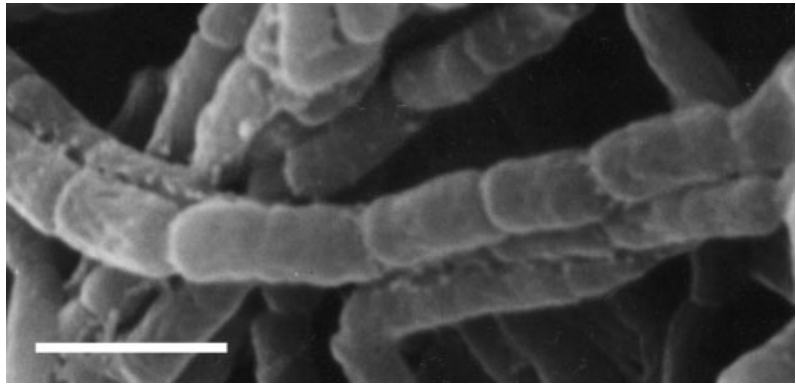

Fig. 1. Micrograph of strain $A B O^{\top}$ grown on ISP2 agar for 7 days at $30{ }^{\circ} \mathrm{C}$, showing the fragmenting aerial mycelium with smoothsurfaced spore-like structures in long, straight to flexuous chains. Bar, $1 \mu \mathrm{m}$.

growth was tested at $10,15,20,25,30,35,45$ and $55{ }^{\circ} \mathrm{C}$ on ISP 2 while the $\mathrm{pH}$ for growth was tested in the range $\mathrm{pH} 2.0-10.0$ in ISP 2 broth $\left(30{ }^{\circ} \mathrm{C}, 180\right.$ r.p.m.). Strain $\mathrm{ABO}^{\mathrm{T}}$ was able to utilize all of the tested carbon sources except xylose, rhamnose and cellulose (Table 1) and could grow in the presence of $5 \% \mathrm{NaCl}$ and up to $100 \mu \mathrm{g}$ lysozyme $\mathrm{ml}^{-1}$. The strain showed a wide tolerance to temperature and $\mathrm{pH}$, in the ranges $15-55{ }^{\circ} \mathrm{C}$ and $\mathrm{pH} 5.0-10.0$.

Copper resistance was measured by incubating cultures at $30{ }^{\circ} \mathrm{C}$ for 4 days on $\mathrm{MM}$ agar with $\mathrm{CuSO}_{4}$ added to different concentrations $(0.5-3 \mathrm{mM})$, as described previously (Albarracín et al., 2005). For this assay, an additional copper-sensitive control, Streptomyces coelicolor DSM $40783^{\mathrm{T}}$, was used. Fig. 2 illustrates the growth of the three strains. While strain $\mathrm{ABO}^{\mathrm{T}}$ was able to grow up to the maximum concentration tested, S. coelicolor DSM $40783^{\mathrm{T}}$ was notably inhibited at $0.5 \mathrm{mM}$, with which sparse substrate mycelium was formed. A. eurytherma DSM $44348^{\mathrm{T}}$ presented a moderate copper-resistance profile but it is clearly lower than that depicted by strain $\mathrm{ABO}^{\mathrm{T}}$. Strain $\mathrm{ABO}^{\mathrm{T}}$ could be distinguished from its closest phylogenetic relatives on the basis of its copper-resistance profile, broader $\mathrm{pH}$ and temperature ranges for growth and differential carbohydrate assimilation and enzymic activity profiles (Table 1).

For chemotaxonomic analyses, strain $\mathrm{ABO}^{\mathrm{T}}$ was grown in trypticase soy broth in flasks on a rotary shaker at 90 r.p.m. and $28{ }^{\circ} \mathrm{C}$ and the biomass was harvested, washed in distilled water and freeze-dried. Cell walls were prepared according to the method of Schleifer (1985). The peptidoglycan structure was studied in whole- and partial-cell-wall hydrolysates using TLC on cellulose (Schleifer \& Kandler, 1972). Analysis of sugars in the purified cell walls was carried out as described by Staneck \& Roberts (1974). Menaquinones were extracted and purified by the method of Minnikin et al. (1984) and analysed by HPLC (Hewlett Packard 1100). Methyl esters of cellular fatty acids from strain $\mathrm{ABO}^{\mathrm{T}}$ were prepared from cells of cultures grown for $24 \mathrm{~h}$ on trypticase soy agar at $28{ }^{\circ} \mathrm{C}$ and 
Table 1. Characteristics of strain $A B O^{\top}$ and its closest phylogenetic relatives in the genus Amycolatopsis

Strains: 1, Amycolatopsis tucumanensis sp. nov. $\mathrm{ABO}^{\mathrm{T}} ; 2, A$ eurytherma DSM 44348 ; 3, A. methanolica IFO $15065^{\mathrm{T}}$; 4, A. thermoflava IFO $14333^{\mathrm{T}}$. Data in columns 1 and 2 were obtained in this study; data in columns 3 and 4 were taken from Kim et al. (2002), Chun et al. (1999) and De Boer et al. (1990). +, Positive; W, weakly positive; -, negative; ND, no data available. All strains form a white aerial mycelium.

\begin{tabular}{|c|c|c|c|c|}
\hline Characteristic & 1 & 2 & 3 & 4 \\
\hline Production of soluble pigment & - & - & - & + \\
\hline \multicolumn{5}{|l|}{ Acid production from: } \\
\hline$(+)$-D-Fructose & $\mathrm{W}$ & + & + & + \\
\hline myo-Inositol & - & + & - & - \\
\hline$(+)$-Raffinose & - & - & - & + \\
\hline$\alpha-(+)$-L-Rhamnose & $\mathrm{w}$ & + & + & - \\
\hline$(-)$-Sucrose & - & - & + & - \\
\hline$(+)$-Trehalose & $\mathrm{w}$ & + & + & + \\
\hline$(+)$-D-Xylose & w & + & + & + \\
\hline \multicolumn{5}{|l|}{ Utilization of: } \\
\hline$(+)$-Cellobiose & - & - & + & + \\
\hline$(+)$-Raffinose & + & - & ND & + \\
\hline$\alpha-(+)$-L-Rhamnose & - & + & + & ND \\
\hline$(+)$-D-Xylose & - & + & + & + \\
\hline \multicolumn{5}{|l|}{ Growth at: } \\
\hline $15{ }^{\circ} \mathrm{C}$ & $\mathrm{w}$ & $\mathrm{w}$ & - & + \\
\hline $20{ }^{\circ} \mathrm{C}$ & + & $\mathrm{w}$ & - & + \\
\hline $25{ }^{\circ} \mathrm{C}$ & + & + & - & + \\
\hline $55^{\circ} \mathrm{C}$ & + & + & - & + \\
\hline \multicolumn{5}{|l|}{ Degradation of: } \\
\hline Aesculin & + & - & $\mathrm{w}$ & + \\
\hline Casein & + & + & - & + \\
\hline Gelatin & + & + & + & - \\
\hline \multicolumn{5}{|l|}{ Production of: } \\
\hline$\beta$-Galactosidase & + & - & ND & ND \\
\hline$N$-Acetyl- $\beta$-glucosaminidase & + & - & ND & ND \\
\hline Nitrate reductase & - & + & + & - \\
\hline Urease & - & + & - & + \\
\hline
\end{tabular}

were analysed by GLC (Schröder et al., 1997). Polar lipids were extracted and identified by two-dimensional TLC
(Minnikin et al., 1984). Chemotaxonomic data also supported the assignment of strain $\mathrm{ABO}^{\mathrm{T}}$ to the genus Amycolatopsis. The micro-organism has a type-IV cell wall (meso-diaminopimelic acid) and a type-A whole-cell sugar pattern, with arabinose, galactose and ribose as the major constituents. The detected phospholipids included phosphatidylinositol, phosphatidylethanolamine, hydroxyl phosphatidylethanolamine and diphosphatidylglycerol, which corresponds to a phospholipid type-II profile. The major menaquinone present was $\mathrm{MK}-9\left(\mathrm{H}_{4}\right)$, and $\mathrm{MK}$ 9( $\left.\mathrm{H}_{2}\right)$, MK-9 $\left(\mathrm{H}_{6}\right)$ and MK-10 $\left(\mathrm{H}_{2}\right)$ were found in minor amounts. Strain $\mathrm{ABO}^{\mathrm{T}}$ contained major amounts of 14methyl pentadecanoic acid (23\%), hexadecanoic acid $(12 \%)$ and 14-methyl hexadecanoic acid (11.4\%). In accordance with its non-acid-alcohol-fastness, mycolic acids were absent in this strain. The complete fatty acid profile is shown in Supplementary Table S1.

DNA extraction and PCR cloning and sequencing of the $16 \mathrm{~S}$ rRNA gene were carried out as described previously (Albarracín et al., 2005). Multiple alignments of the $16 \mathrm{~S}$ rRNA gene sequences from strain $\mathrm{ABO}^{\mathrm{T}}$ (1488 nt) and reference sequences from the NCBI databases were performed by using the CLUSTAL $\mathrm{W}$ program (Thompson et al., 1994). A phylogenetic tree was constructed according to the neighbour-joining method (Saitou \& Nei, 1987) using the maximum-composite-likelihood method (Tamura et al., 2004) and compared with a tree constructed according to the maximum-parsimony method (Fitch, 1971). In both cases, 1000 resamplings were used for bootstrap analyses (Felsenstein, 1985). All analyses were carried out with the MEGA4 program (Kumar et al., 2001). The phylogenetic analysis with corresponding nucleotide sequences from representatives of the family Pseudonocardiaceae showed that the organism belongs to the genus Amycolatopsis (Fig. 3 and Supplementary Fig. S2). It is clear from the phylogenetic trees that strain $\mathrm{ABO}^{\mathrm{T}}$ forms a monophyletic clade with A. eurytherma NT202 ${ }^{\mathrm{T}}$. This relationship is supported by the $100 \%$ bootstrap value for the node in the neighbour-joining tree. The 16S rRNA gene sequence similarity between strain $\mathrm{ABO}^{\mathrm{T}}$ and $A$. eurytherma $\mathrm{NT} 202^{\mathrm{T}}$ is $99.8 \%$; this value corresponds to two differences in the 1466 nucleotide positions that were

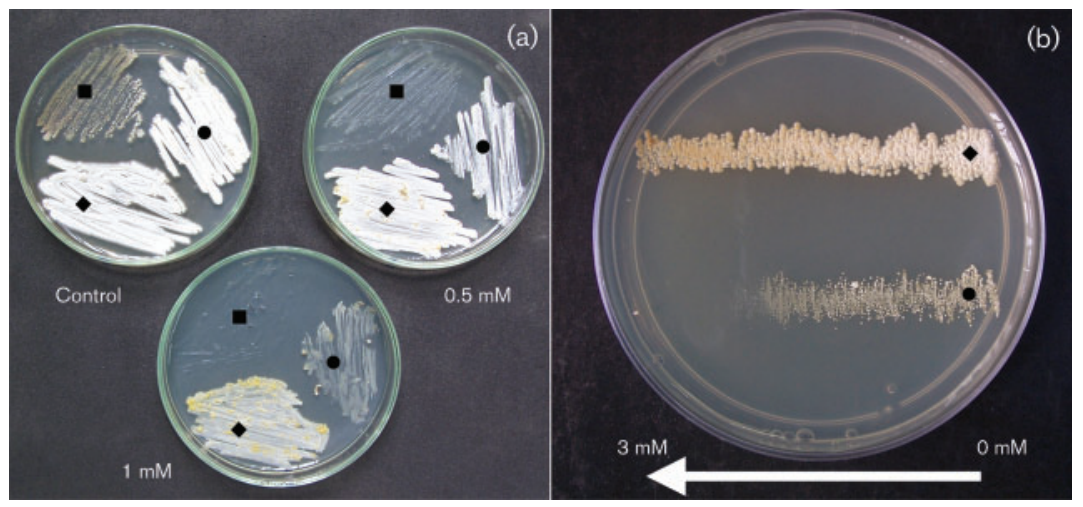

Fig. 2. Copper-resistance assays for $S$. coelicolor DSM $40783^{\top}(\boldsymbol{\square})$, A. eurytherma DSM $44348^{\top}(\bullet)$ and strain $\mathrm{ABO}^{\top}(\boldsymbol{)})$ on MM agar plates supplemented with 0.5 or $1 \mathrm{mM}$ copper sulphate (a) and $A$. eurytherma DSM $44348^{\top}$ $(\bullet)$ and strain $\mathrm{ABO}^{\top}(\boldsymbol{)})$ inoculated on $\mathrm{MM}$ agar plates with a copper sulphate gradient (0-3 $\mathrm{mM}$; arrow indicates the direction of increasing copper concentration) (b). 


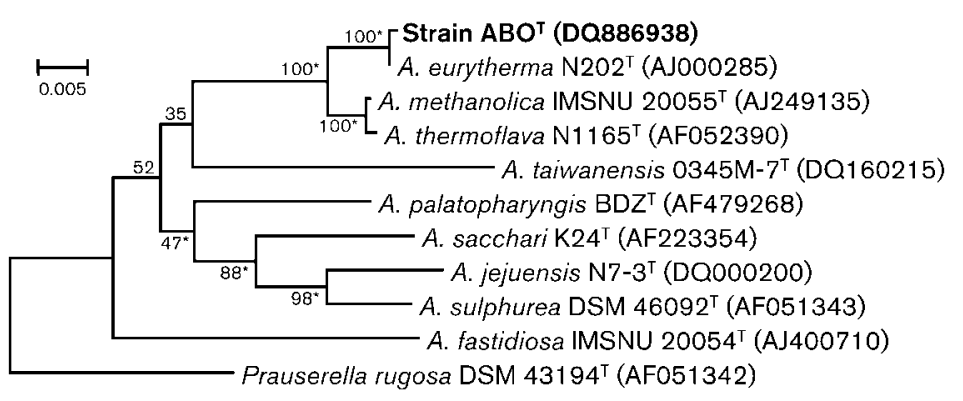

Fig. 3. Neighbour-joining tree based on nearly complete 16S rRNA gene sequences (at least $1402 \mathrm{nt}$ ) showing the relationships between strain $\mathrm{ABO}^{\top}$ and its closest phylogenetic relatives in the genus Amycolatopsis. Percentages at nodes are levels of bootstrap support based on 1000 resamplings. Asterisks indicate that the corresponding nodes were also recovered in trees generated with the maximumparsimony method. Prauserella rugosa DSM $43194^{\top}$ was used as the outgroup. Bar, 0.005 substitutions per nucleotide position. compared. Similarity values with other Amycolatopsis strains ranged from 93 to $99.8 \%$.

DNA for DNA-DNA hybridization was isolated using a French pressure cell and purified by chromatography on hydroxyapatite as described by Cashion et al. (1977). DNA-DNA hybridization was carried out as described by De Ley et al. (1970) with some modifications (Huß et al., 1983) using a model Cary 100 Bio UV/Vis spectrophotometer. The DNA-DNA relatedness of strain $\mathrm{ABO}^{\mathrm{T}}$ to $A$. eurytherma DSM $44348^{\mathrm{T}}$ was $39.5 \%$, indicating that they were distinct genomospecies based on the criteria set by Stackebrandt et al. (2002).

In summary, strain $\mathrm{ABO}^{\mathrm{T}}$ could be distinguished from its closest phylogenetic neighbours, including A. eurytherma, by combined results from phenotypic and molecular tests (Figs 1, 2 and 3 and Table 1). It is evident from these genotypic and phenotypic data that strain $\mathrm{ABO}^{\mathrm{T}}$ represents a novel species in the genus Amycolatopsis. It is proposed that the organism be assigned to the novel species Amycolatopsis tucumanensis sp. nov.

\section{Description of Amycolatopsis tucumanensis sp. nov.}

Amycolatopsis tucumanensis (tu.cu.ma.nen'sis. N.L. fem. adj. tucumanensis pertaining to Tucumán, Argentina, the origin of the soil sample from which the type strain was isolated).

Aerobic, Gram-positive, non-acid-alcohol-fast, catalasepositive, non-motile actinomycete that forms an extensively branched, honey-yellow substrate mycelium which fragments into squarish elements on all ISP media tested (RAL colour code 1024). White, spore-producing aerial mycelium (RAL colour code 9003) is only formed on ISP 2, 5 and 7 and MM agar and also fragments. The spore-like structures $(0.3 \times 0.8-1.5 \mu \mathrm{m})$ present smooth surfaces and are displayed in long, straight to flexuous chains. No diffusible pigments are produced with any tested media. Produces phosphatase, but not nitrate reductase nor urease. Grows at $15-55{ }^{\circ} \mathrm{C}$ and $\mathrm{pH} 5-10$ and with $5 \%$ $\mathrm{NaCl}$. Resistant to lysozyme $\left(100 \mu \mathrm{g} \mathrm{ml}^{-1}\right)$ and to high concentrations of copper (up to $3 \mathrm{mM}$ ). Other phenotypic properties are given in Table 1.
The type strain is $\mathrm{ABO}^{\mathrm{T}}$ (=DSM $45259^{\mathrm{T}}=\mathrm{BCCM} / \mathrm{LMG}$ $\left.24814^{\mathrm{T}}\right)$, which was isolated from a sediment sample polluted with copper and collected in Tucumán, Argentina. The species description is based on a single strain and hence serves as the type strain description.

\section{Acknowledgements}

This work was supported by CIUNT, FONCyT and CONICET, Argentina. V.H. A. was a CONICET Doctoral Fellow. The authors gratefully acknowledge the assistance of $\mathrm{Mr}$ Guillermo Borchia (laboratory assistant) and Lic. Ana Lucía Avila. Chemotaxonomic and DNA-DNA hybridization analyses were carried out by the DSMZ staff.

\section{References}

Albarracín, V. H., Amoroso, M. J. \& Abate, C. M. (2005). Isolation and characterization of indigenous copper-resistant actinomycete strains. Chem Erde Geochem 65 (Suppl. 1), 145-156.

Albarracín, V. H., Winik, B., Kothe, E., Amoroso, M. J. \& Abate, C. M. (2008a). Copper bioaccumulation by the actinobacterium Amycolatopsis sp. ABO. J Basic Microbiol 48, 323-330.

Albarracin, V. H., Avila, A. L., Amoroso, M. J. \& Abate, C. M. (2008b). Copper removal ability by Streptomyces strains with dissimilar growth patterns and endowed with cupric reductase activity. FEMS Microbiol Lett 288, 141-148.

Amoroso, M. J., Castro, G. R., Durán, A., Peraud, O., Oliver, G. \& Hill, R. T. (1998). Screening of heavy metal-tolerant actinomycetes isolated from the Salí River. J Gen Appl Microbiol 44, 129-132.

Cashion, P., Holder-Franklin, M. A., McCully, J. \& Franklin, M. (1977). A rapid method for the base ratio determination of bacterial DNA. Anal Biochem 81, 461-466.

Chun, J., Kim, S. B., Oh, Y. K., Seong, C.-N., Lee, D.-H., Kyung, S. B., Lee, K.-S., Kang, S.-O., Yung, C. H. \& Goodfellow, M. (1999). Amycolatopsis thermoflava sp. nov., a novel soil actinomycete from Hainan Island, China. Int J Syst Bacteriol 49, 1369-1373.

De Boer, L., Dijkhuizen, L., Grobben, G., Goodfellow, M., Stackebrandt, E., Parlett, J. H., Whitehead, D. \& Witt, D. (1990). Amycolatopsis methanolica sp. nov. a facultatively methylotrophic actinomycete. Int J Syst Bacteriol 40, 194-204.

De Ley, J., Cattoir, H. \& Reynaerts, A. (1970). The quantitative measurement of DNA hybridization from renaturation rates. Eur $J$ Biochem 12, 133-142.

Doetsch, R. N. (1981). Determinative methods of light microscopy. In Manual of Methods for General Bacteriology, pp. 21-23. Edited by 
P. Gerhardt, R. G. E. Murray, R. N. Costilow, E. W. Nester, W. A. Wood, N. R. Krieg \& G. B. Phillips. Washington, DC: American Society for Microbiology.

Felsenstein, J. (1985). Confidence limits on phylogenies: an approach using the bootstrap. Evolution 39, 783-791.

Fitch, W. M. (1971). Toward defining the course of evolution: minimum change for a specific tree topology. Syst Zool 20, 406-416.

Gordon, R. E., Barnett, D. A., Handerhan, J. E. \& Pang, C. H.-N. (1974). Nocardia coeliaca, Nocardia autotrophica, and the nocardin strain. Int J Syst Bacteriol 24, 54-63.

Huß, V. A. R., Festl, H. \& Schleifer, K. H. (1983). Studies on the spectrophotometric determination of DNA hybridization from renaturation rates. Syst Appl Microbiol 4, 184-192.

Kim, S. B. \& Goodfellow, M. (1999). Reclassification of Amycolatopsis rugosa Lechevalier et al. 1986 as Prauserella rugosa gen. nov., comb. nov. Int J Syst Bacteriol 49, 507-512.

Kim, B., Sahin, N., Tan, G. Y. A., Zakrzewska-Czerwinska, J. \& Goodfellow, M. (2002). Amycolatopsis eurytherma sp. nov., a thermophilic actinomycete isolated from soil. Int $J$ Syst Evol Microbiol 52, 889-894.

Kumar, S., Tamura, K., Jakobsen, I. B. \& Nei, M. (2001). MEGA2: molecular evolutionary genetics analysis software. Bioinformatics 17, 1244-1245.

Lechevalier, M. P., Prauser, H., Labeda, D. P. \& Ruan, J.-S. (1986), Two new genera of nocardioform actinomycetes: Amycolata gen. nov. and Amycolatopsis gen. nov. Int J Syst Bacteriol 36, 29-37.

Minnikin, D. E., O'Donnell, A. G., Goodfellow, M., Alderson, G., Athalye, M., Schaal, A. \& Parlett, J. H. (1984). An integrated procedure for the extraction of bacterial isoprenoid quinones and polar lipids. J Microbiol Methods 2, 233-241.

Polti, M. A., Amoroso, M. J. \& Abate, C. M. (2007). Chromium (VI) resistance and removal by actinomycete strains isolated from sediments. Chemosphere 67, 660-667.

Richards, J. W., Krumholz, G. D., Chval, M. S. \& Tisa, L. S. (2002). Heavy metal resistance patterns of Frankia strains. Appl Environ Microbiol 68, 923-927.

Saitou, N. \& Nei, M. (1987). The neighbor-joining method: a new method for reconstructing phylogenetic trees. Mol Biol Evol 4, 406-425.
Schleifer, K. H. (1985). Analysis of the chemical composition and primary structure of murein. Methods Microbiol 18, 123-156.

Schleifer, K. H. \& Kandler, O. (1972). Peptidoglycan types of bacterial cell walls and their taxonomic implications. Bacteriol Rev 36, 407-477.

Schmidt, A., Haferburg, G., Siñeriz, M., Merten, D., Büchel, G. \& Kothe, E. (2005). Heavy metal resistance mechanisms in actinobacteria for survival in AMD contaminated soils. Chem Erde Geochem 65 (Suppl. 1), 131-144.

Schröder, K.-H., Naumann, L., Kroppenstedt, R. M. \& Reischl, U. (1997). Mycobacterium hassiacum sp. nov., a new rapidly growing thermophilic mycobacterium. Int J Syst Bacteriol 47, 86-91.

Shirling, E. B. \& Gottlieb, D. (1966). Methods for characterization of Streptomyces species. Int J Syst Bacteriol 16, 313-340.

Solioz, M. \& Stoyanov, J. V. (2003). Copper homeostasis in Enterococcus hirae. FEMS Microbiol Rev 27, 183-195.

Stackebrandt, E., Rainey, F. A. \& Ward-Rainey, N. L. (1997). Proposal for a new hierarchic classification system, Actinobacteria classis nov. Int J Syst Bacteriol 47, 479-491.

Stackebrandt, E., Frederiksen, W., Garrity, G. M., Grimont, P. A. D., Kämpfer, P., Maiden, M. C. J., Nesme, X., Rosselló-Mora, R., Swings, J. \& other authors (2002). Report of the ad hoc committee for the re-evaluation of the species definition in bacteriology. Int $J$ Syst Bacteriol 52, 1043-1047.

Staneck, J. L. \& Roberts, G. D. (1974). Simplified approach to the identification of aerobic actinomycetes by thin-layer chromatography. Appl Microbiol 28, 226-231.

Tamura, K., Nei, M. \& Kumar, S. (2004). Prospects for inferring very large phylogenies by using the neighbor-joining method. Proc Natl Acad Sci U S A 101, 11030-11035.

Thompson, J. D., Higgins, D. \& Gibson, T. J. (1994). ClustaL W: improving the sensitivity of progressive multiple sequence alignment through sequence weighting, position-specific gap penalties and weight matrix choice. Nucleic Acids Res 22, 4673-4680.

Wink, J., Gandhi, J., Kroppenstedt, R. M., Seibert, G., Sträubler, B., Schumann, P. \& Stackebrandt, E. (2004). Amycolatopsis decaplanina sp. nov., a novel member of the genus with unusual morphology. Int $J$ Syst Evol Microbiol 54, 235-239. 